\title{
OPEN Direct synthesis of nanostructured silver antimony sulfide powders from metal xanthate precursors
}

\begin{abstract}
Yasser T. Alharbi ${ }^{1}$, Firoz Alam ${ }^{1}$, Abdelmajid Salhi ${ }^{3}$, Mohamed Missous $^{3}$ \& David J. Lewis ${ }^{2 \bowtie}$
Silver(I) ethylxanthate $\left[\mathrm{AgS}_{2} \mathrm{COEt}\right](1)$ and antimony(III) ethylxanthate $\left[\mathrm{Sb}\left(\mathrm{S}_{2} \mathrm{COEt}\right)_{3}\right](2)$ have been synthesised, characterised and used as precursors for the preparation of $\mathrm{AgSbS}_{2}$ powders and thin films using a solvent-free melt method and spin coating technique, respectively. The as-synthesized $\mathrm{AgSbS}_{2}$ powders were characterized by powder X-ray diffraction (XRD), Raman spectroscopy, scanning electron microscopy (SEM) and energy dispersive X-ray (EDX) spectroscopy. The crystalline $\mathrm{AgSbS}_{2}$ powder was investigated using XRD, which shows that $\mathrm{AgSbS}_{2}$ has cuboargyrite as the dominant phase, which was also confirmed by Raman spectroscopy. SEM was also used to study the morphology of the resulting material which is potentially nanostructured. EDX spectra gives a clear indication of the presence of silver $(\mathrm{Ag})$, antimony $(\mathrm{Sb})$ and sulfur $(\mathrm{S})$ in material, suggesting that decomposition is clean and produces high quality $\mathrm{AgSbS}_{2}$ crystalline powder, which is consistent with the XRD and Raman data. Electronic properties of $\mathrm{AgSbS}_{2}$ thin films deposited by spin coating show a p-type conductivity with measured carrier mobility of $81 \mathrm{~cm}^{2} \mathrm{~V}^{-1} \mathrm{~s}^{-1}$ and carrier concentration of $1.9 \times 10^{15} \mathrm{~cm}^{-3}$. The findings of this study reveal a new bottom-up route to these compounds, which have potential application as absorber layers in solar cells.
\end{abstract}

Considerable research attention has been focused on the application of binary, ternary and quaternary chalcogenides as absorber layers in thin film solar cells ${ }^{1-3}$. Metal chalcogenides have gained interest due to their potential in ferroelectric, thermoelectric devices and for their non-linear optical properties ${ }^{4-11}$. Copper indium gallium selenide (CIGS) and cadmium telluride (CdTe) are the most commonly used light-absorbing materials in thin film solar cell ${ }^{12}$. However, low cost, earth-abundant and cadmium-free materials can potentially be used as an alternative ${ }^{13}$

The creation of inorganic ternary materials containing three elements is desirable due to the range of possible new materials with novel electronic properties. As such, there has been significant scientific interest in the synthesis of such materials, and more specifically, ternary chalcogenides, for the fabrication of highly efficient, cheap and environmentally friendly photovoltaic devices ${ }^{14}$. Such ternary materials can be produced by mixing elements from different groups of the periodic table such as $\mathrm{NiCo}_{2} \mathrm{~S}_{4}{ }^{15}$ and $\mathrm{Ag}_{8} \mathrm{SnS}_{6}{ }^{16}$. Focusing on I-III- $\mathrm{VI}_{2}$-type and $\mathrm{I}-\mathrm{III}_{2}-\mathrm{VI}_{4}$-types, which include elements from group I (Cu, Ag), group III ( $\mathrm{Ga}$ and In) and group VI (S and $\mathrm{Se})$ results in chalcopyrite-type materials. These are desirable due to their reduced toxicity, and high absorption coefficients extending across the visible to near-infrared wavelengths ${ }^{17}$.

A variety of compounds, including $\mathrm{CuSbS}_{2}(\mathrm{Eg}=1.5 \mathrm{eV}), \mathrm{SnS}(\mathrm{Eg}=1.1 \mathrm{eV}), \mathrm{Cu}_{2} \mathrm{SnS}_{3}(\mathrm{Eg}=1.15 \mathrm{eV}) \mathrm{AgSbSe}_{2}$ $(\mathrm{Eg}=1 \mathrm{eV})$ and $\mathrm{AgSbS}_{2}(\mathrm{Eg}=1.7 \mathrm{eV})$ have desirable optical properties for solar cell applications, mainly due to their bandgap commensurate with AM $1.5 \mathrm{G}$ photon flux maxima ${ }^{18-22}$.

Interest in chalcogenides such as $\mathrm{AAsSe}_{2}(\mathrm{~A}=\mathrm{Li}, \mathrm{Na})$ and $\mathrm{AgSbEQ}_{2}(\mathrm{EQ}=\mathrm{S}, \mathrm{Se})$ has predominantly been due to the distinct ferroelectric, thermoelectric and non-linear optical properties they present ${ }^{23-26}$. Alloys consisting of $\mathrm{AgSbSe}_{2}$ have potential use in solar cells due to their high optical-absorption coefficient of $>10^{4} \mathrm{~cm}^{-1}$ across the Vis-NIR region of the electromagnetic spectrum and band gap energies of $0.9-1.1 \mathrm{eV}$, which can maximise the theoretical power conversion efficiency according the Shockley-Queisser limit (ca. 24\% at these values of $\left.\mathrm{E}_{\mathrm{g}}\right)^{27-29}$. Usually, $\mathrm{AgSbSe}_{2}$ crystallises in the halite structure, whereby Ag and Sb randomly occupy the crystallographic Wyckoff positions ${ }^{30}$. The AgSbS 2 ternary chalcogenide may be modified to give rise to quaternary compounds of the form $(\mathrm{MS})_{1-\mathrm{x}}\left(\mathrm{AgSbS}_{2}\right)_{\mathrm{x}}(\mathrm{M}=\mathrm{Ge}, \mathrm{Sn}, \mathrm{Pb})$, which represent a family of semiconductors and semi-metals with low to narrow optical band gap energies in the range $0.01-0.6 \mathrm{eV}^{31,32}$. At elevated temperatures, $\mathrm{AgSbS}_{2}$ exists as

${ }^{1}$ Department of Chemistry, The University of Manchester, Oxford Road, Manchester M13 9PL, UK. ${ }^{2}$ Department of Materials, The University of Manchester, Oxford Road, Manchester M13 9PL, UK. ${ }^{3}$ Department of Electrical and Electronic Engineering, The University of Manchester, Sackville Street, Manchester M13 9PL, UK. ${ }^{\square}$ email: david.lewis-4@manchester.ac.uk 

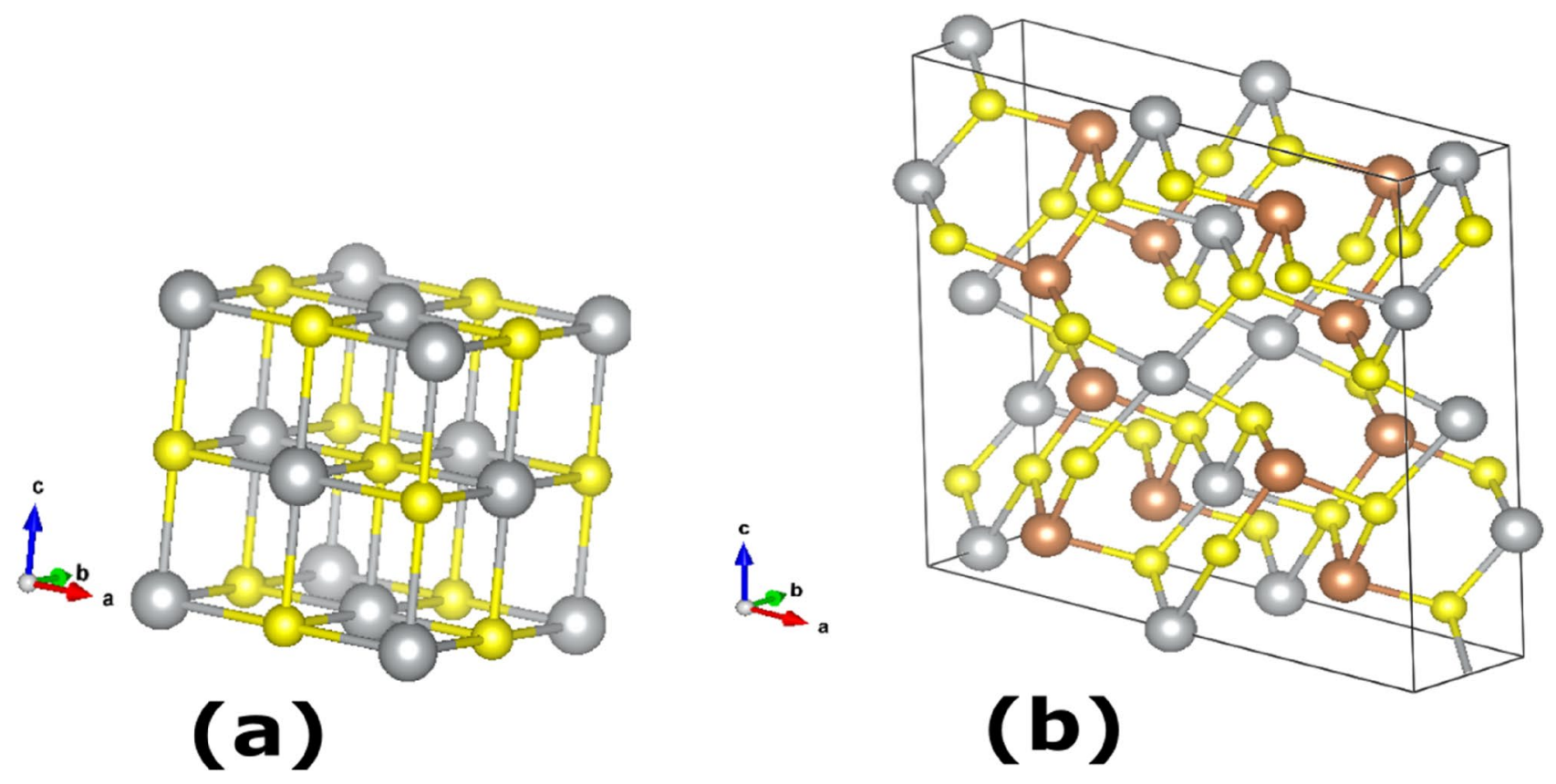

Figure 1. (a) Crystal structure of cubic cuboargyrite $\beta-\mathrm{AgSbS}_{2}$ as reported by Geller and Wernick, with the silver and antimony indistinguishable ${ }^{33}$. (b) Crystal structure of monoclinic $\alpha-\mathrm{AgSbS}_{2}$ miargyrite as obtained by $\mathrm{Smith}^{34}$; silver atoms $(\mathrm{Ag})$ are represented by silver spheres, Antimony $(\mathrm{Sb})$ by brown spheres and $\mathrm{S}$ by yellow spheres.

cubic $\beta-\mathrm{AgSbS}_{2}{ }^{33}$, whilst at low temperatures $\left(<380{ }^{\circ} \mathrm{C}\right)$ monoclinic $\alpha-\mathrm{AgSbS}_{2}{ }^{33}$ is the dominant phase (Fig. 1) 33-35. The crystalline structure of $\alpha-\mathrm{AgSbS}_{2}$ has been studied over a number of decades by a series of authors, including Hofmann $(1938)^{36}$, Knowles $(1964)^{37}$ and Smith et al., (1997) ${ }^{34}$. Effenberger et al. (2002) demonstrated that the structure is comprised of pyramids of $\mathrm{SbS}_{3}$ and chains linked by linear S-Ag-S and $\mathrm{AgS}_{4}$ polyhedra $^{38}$.

A variety of techniques have been established for the formation of $\mathrm{AgSbS}_{2}$ thin films including thermal evaporation $^{39}$, pulsed-laser deposition ${ }^{40}$, RF-magnetron sputtering ${ }^{41}$ and laser ablation ${ }^{42}$. For each of the above techniques the starting material is prepared by direct fusion of stoichiometric quantities of the elements, which can be problematic due to the formation of sub phases caused by inequivalent ion migration rates in the solid state. The use of metal xanthate precursors, however, may circumvent this problem as the mixing prior to thermal decomposition occurs at the nanoscale and hence final products should be homogeneous and of a single crystalline phase, with the bottom up nature of the process allowing for exquisite control of elemental constitution. Due to the pre-formed bonds between metal and chalcogenide atoms, metal xanthates can act as efficient precursors for the formation of solid state metal sulfides. This has led to the extensive application of, for instance, xanthate complexes for the production of thin films $\mathrm{s}^{43,44}$. Advantages conferred by this sort of synthetic route include the ability to carry out low temperature decomposition, the ease of synthesis and stability of the resulting compound in air, along with the fact that by-products for these materials are generally gaseous. O'Brien \& Lewis have reported a number of such syntheses for a range of main group and transition metal sulfides ${ }^{45-50}$.

In this paper, we describe a metal xanthate precursor route to produce ternary silver antimony sulfide $\left(\mathrm{AgSbS}_{2}\right)$ as a single well-defined phase via thermal decomposition of metal xanthate precursors in stoichiometric ratios. $\mathrm{AgSbS}_{2}$ is rarely found in nature but possesses potentially excellent properties for solar cell applications ${ }^{51,52}$.

\section{Results and discussion}

Metal xanthate complexes of the form $\left[\mathrm{AgS}_{2} \mathrm{COEt}\right](\mathbf{1})$ and $\left[\mathrm{Sb}\left(\mathrm{S}_{2} \mathrm{COEt}\right)_{3}\right](2)$ were synthesised via metathesis reactions of the nitrate/chloride metal salts with potassium ethyl xanthate ${ }^{52-54}$. Infrared (IR) and nuclear magnetic resonsnce (NMR) spectroscopies were used to assess the purity of complexes (1) and (2) and the spectra recorded are shown in the ESI (Fig. S1.1 and S1.2). The $\mathrm{Ag}_{2} \mathrm{~S}$ and $\mathrm{Sb}_{2} \mathrm{~S}_{3}$ powders synthesised from $\left[\mathrm{AgS}_{2} \mathrm{COEt}\right]$ (1) and $\left[\mathrm{Sb}\left(\mathrm{S}_{2} \mathrm{COEt}\right)_{3}\right](2)$ at three different temperatures $\left(400^{\circ} \mathrm{C}, 450^{\circ} \mathrm{C}\right.$ and $\left.500{ }^{\circ} \mathrm{C}\right)$ were then characterised using XRD shows a pure phase Acanthite $\mathrm{Ag}_{2} \mathrm{~S}$ (Fig. S2.1) and stable Stibnite phase of $\mathrm{Sb}_{2} \mathrm{~S}_{3}$ (Fig. S2.2), respectively. The Raman spectra of both metal sulfide $\left(\mathrm{Ag}_{2} \mathrm{~S}\right.$ and $\left.\mathrm{Sb}_{2} \mathrm{~S}_{3}\right)$ synthesised from precursors (1) and (2) at three different temperatures $\left(400^{\circ} \mathrm{C}, 450^{\circ} \mathrm{C}\right.$ and $\left.500^{\circ} \mathrm{C}\right)$ are shown in Figs. S2.3 and S2.4, respectively.

Thermogravimetric analysis of $\left[\mathrm{AgS}_{2} \mathrm{COEt}\right](1)$ and $\left[\mathrm{Sb}\left(\mathrm{S}_{2} \mathrm{COEt}\right)_{3}\right](2)$ complexes. Thermogravimetric analysis of (1) and (2) was performed in the temperature range of $0{ }^{\circ} \mathrm{C}$ to $550{ }^{\circ} \mathrm{C}$ under a nitrogen atmosphere. Both complexes exhibited a large mass loss between 80 and $250^{\circ} \mathrm{C}$ (Fig. 2). The decomposition of (1) started at $96^{\circ} \mathrm{C}$ and ended at $177^{\circ} \mathrm{C}$ with the remaining weight determined to be $54 \%$, which is matching the calculated value of $54 \%$. Both experimental and theoretical values confirmed the phase of $\mathrm{Ag}_{2} \mathrm{~S}$. In a similar manner, the TGA profile of (2) exhibits the main decomposition step between 100 and $161{ }^{\circ} \mathrm{C}$. The final residue 


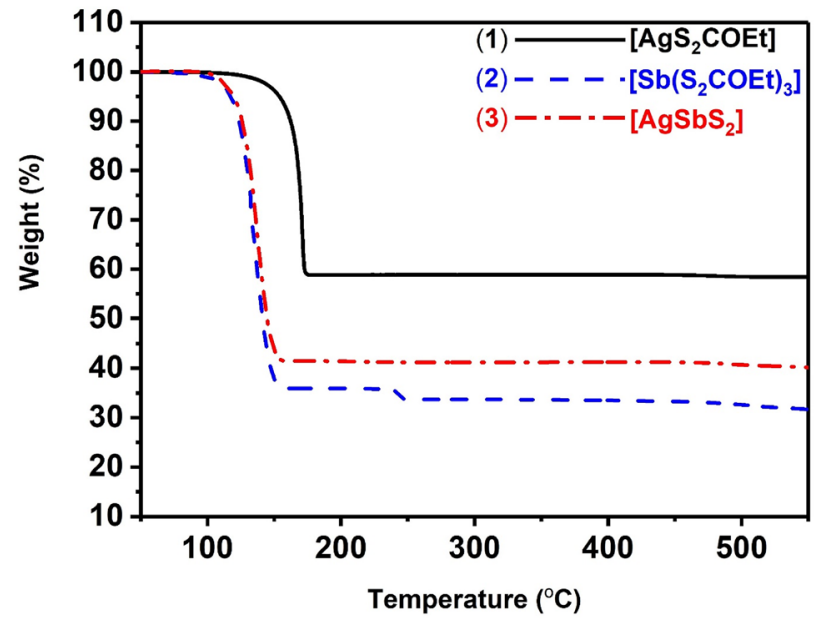

Figure 2. Thermogravimetric analysis (TGA) profiles of (1) $\left[\mathrm{AgS}_{2} \mathrm{COEt}\right]$, (2) $\left[\mathrm{Sb}\left(\mathrm{S}_{2} \mathrm{COEt}\right)_{3}\right]$, and (3) mixtures of $\mathrm{Ag}$ and $\mathrm{Sb}$ xanthates to form $\mathrm{AgSbS}_{2}$.

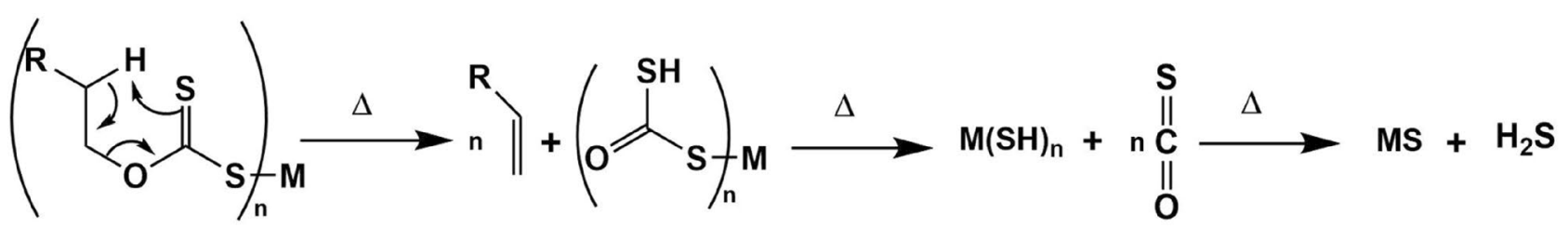

Scheme 1. Metal xanthate pyrolysis by the Chugaev elimination mechanism to produce metal sulfide $\mathrm{MS}^{62,63}$.

of $35 \%$ is in good agreement with the calculated value of $35 \%$ which confirms the formation of $\mathrm{Sb}_{2} \mathrm{~S}_{3}$. The minor decomposition step with $<3 \%$ mass loss is attributed to loss of sulfur which was also observed by Alqhatani et $a l^{54}$. TGA of mixtures of the two complexes (Fig. 2) shows a single step decomposition at ca. $200{ }^{\circ} \mathrm{C}$ with a remaining weight of $41 \%$ which corresponds to the formation of $\mathrm{AgSbS}_{2}$. This low temperature decomposition of the complexes to produce $\mathrm{AgSbS}_{2}$ means that it could potentially be produced within polymer matrices and can be used as an absorber layers in polymer nanocrystal based hybrid solar cells ${ }^{55-57}$. O'Brien et al. has reported the preparation of $\mathrm{PbS}$ nanocrystals in polymer matrix via decomposition of lead(II) xanthates in polystyrene matrices as a potential absorber material for flexible hybrid photovoltaic devices ${ }^{58}$.

The mixtures of the solid precursors form a homogenous molten intermediate reactive melt, when the temperature increased. Before undergoing decomposition to form the final solid products. The volatile organic components are evacuated through the constant nitrogen flow ${ }^{53,59,60}$. The mechanism of xanthate decomposition follows a Chugaev elimination reaction which involves the production of a cyclic transition state to produce carbonyl sulfide molecules (OCS) and alkenic side products (Scheme 1) ${ }^{61,62}$. Alanazi et al. has previously reported the synthesis of stannite $\mathrm{Cu}_{2} \mathrm{FeSnS}_{4}$ (CFTS) quaternary chalcogenides from mixtures of metal (O-ethylxanthato) $(\mathrm{M}=\mathrm{Cu}, \mathrm{Fe}$ and $\mathrm{Sn})$ complexes, which shows that combining xanthate precursors in tandem in reactive melts is a promising approach to these materials ${ }^{63}$.

Therefore, pyrolysis of mixtures of $\mathrm{Ag}$ and $\mathrm{Sb}$ precursors was carried out at various temperature such as $\left(300^{\circ} \mathrm{C}, 350^{\circ} \mathrm{C} 400^{\circ} \mathrm{C}, 450^{\circ} \mathrm{C}\right.$ and $500{ }^{\circ} \mathrm{C}$ ). The powder XRD pattern of $A_{g S b S}$ powders synthesised at 300 and $350^{\circ} \mathrm{C}$ have some impurity peaks as shown in ESI (Fig. S2.5). The XRD powder pattern of polycrystalline $\mathrm{AgSbS}_{2}$ powders synthesised at $400^{\circ} \mathrm{C}$ can be ascribed to cubic $\mathrm{AgSbS}_{2}$ (cuboargyrite, ICDD No. 00-017-0456, space group [Fm-3 m] and $a=5.6520 \AA$ ) with Bragg peaks at $2 \theta=27.4^{\circ}, 31.7^{\circ}, 45.3^{\circ}, 53.7^{\circ}, 56.7^{\circ}, 66.0^{\circ}, 72.8^{\circ}, 75.0^{\circ}$

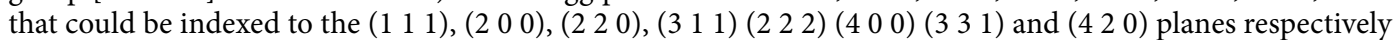
(Fig. 3). The positions of the peaks in Fig. 3 a (black line) are shifted toward smaller $2 \theta$ values with respect to those observed in Fig. $3 b$ and c. Since all the peaks are shifted by same $2 \theta$ value, it is likely that this is a measurement error associated with the height of the sample in the diffractometer. Additionally, we have also observed that the peaks become more intense and the FWHM of each peak is reduced when the synthesis temperature was increased from 400 to $500{ }^{\circ} \mathrm{C}$. The average crystallite domain size of $\mathrm{AgSbS}_{2}$ powders synthesised at $400{ }^{\circ} \mathrm{C}$, $450{ }^{\circ} \mathrm{C}$ and $500{ }^{\circ} \mathrm{C}$ are $34 \mathrm{~nm}, 43 \mathrm{~nm}$ and $59 \mathrm{~nm}$ respectively, as calculated using Scherrer's equation ${ }^{64}$ (Fig. 4). The crystallite domain size found in $\mathrm{AgSbS}_{2}$ powders increases with increasing synthesis temperature, which is in agreement with previously reported data ${ }^{65-67}$.

Raman spectroscopy was conducted on the $\mathrm{AgSbS}_{2}$ powder produced at $500^{\circ} \mathrm{C}$ (Fig. 5). Raman resonances are observed at $80.2,115.4,185.9,249.2,368.9$ and $448.1 \mathrm{~cm}^{-1}$ respectively, and the spectral positions of these peaks agree with those reported previously for $\mathrm{AgSbS}_{2}{ }^{68}$. The electrical properties of $\mathrm{AgSbS}_{2}$ films were measured using the Van Der Pauw method. Silver paste was used to form the four contacts on $7 \times 7 \mathrm{~mm}^{2}$ sample area. The 


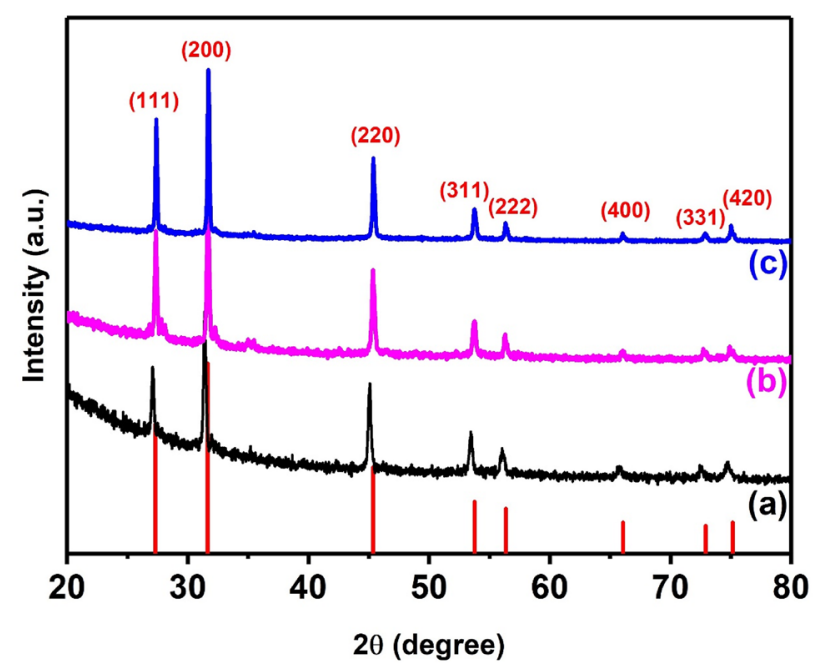

Figure 3. XRD patterns of $\mathrm{AgSbS}_{2}$ powders synthesised at various temperatures (a) $400{ }^{\circ} \mathrm{C}(\mathbf{b}) 450{ }^{\circ} \mathrm{C}$, and (c) $500{ }^{\circ} \mathrm{C}$ for $1 \mathrm{~h}$ under nitrogen. The red sticks correspond to the standard powder diffraction pattern of cubic $\mathrm{AgSbS}_{2}$ (cuboargyrite, ICDD No. 00-017-0456).

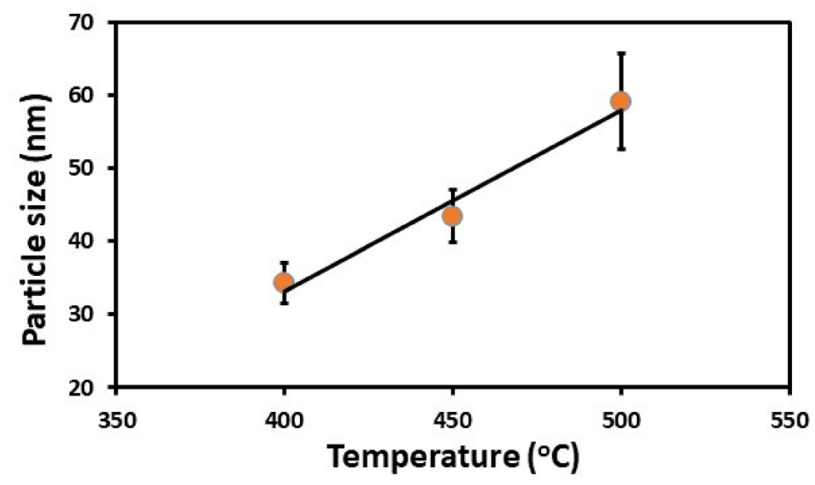

Figure 4. Average crystallite domain size of $\mathrm{AgSbS}_{2}$ powders calculated using Scherrer's equation as a function of synthesis temperature.

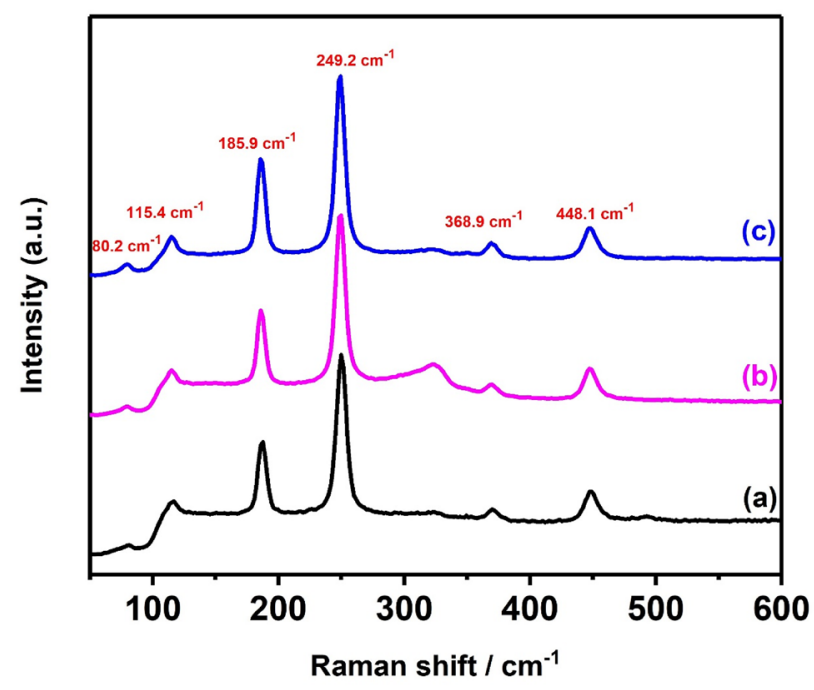

Figure 5. Raman spectra of $\mathrm{AgSbS}_{2}$ powders synthesised at different temperatures (a) $400{ }^{\circ} \mathrm{C},(\mathbf{b}) 450{ }^{\circ} \mathrm{C}$ and (c) $500{ }^{\circ} \mathrm{C}$ for $1 \mathrm{~h}$ under nitrogen. 

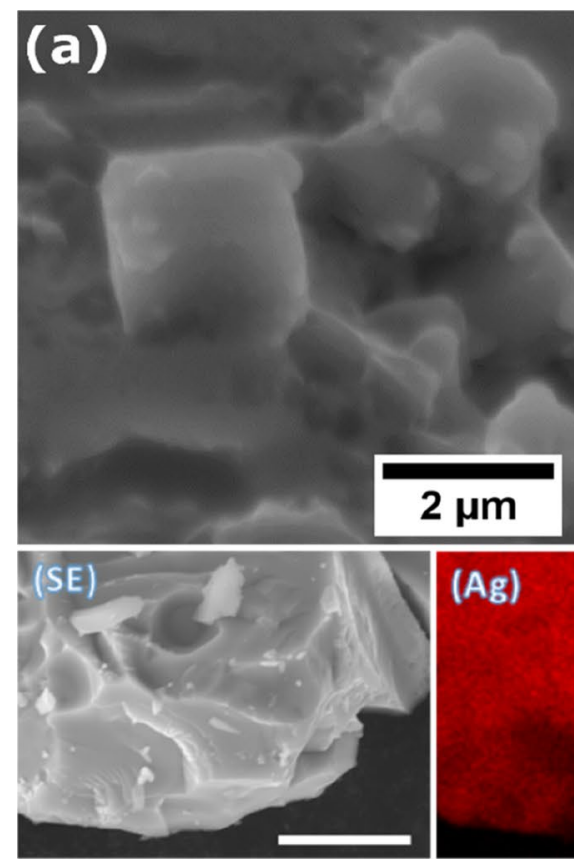
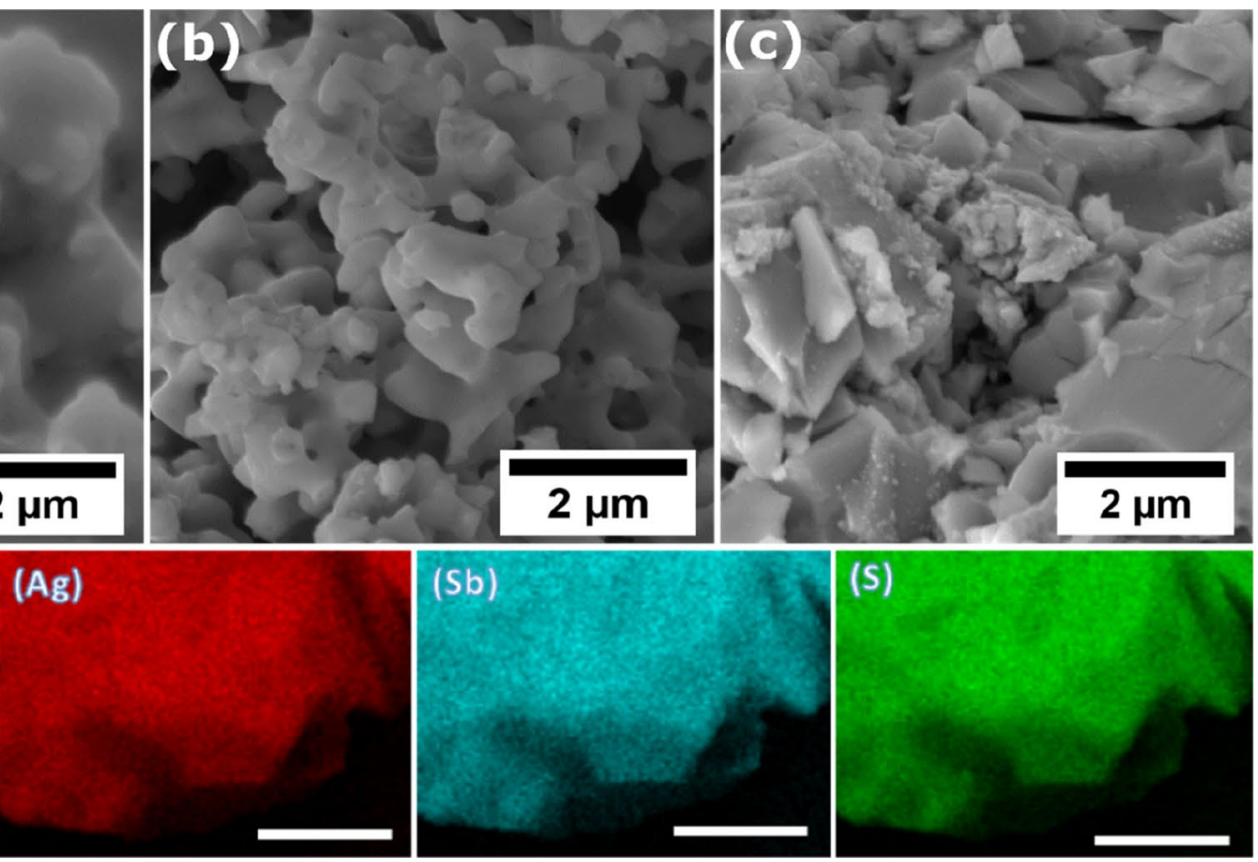

Figure 6. Top: SEM images of $\mathrm{AgSbS}_{2}$ powders produced at (a) 400, (b) 450 and (c) $500{ }^{\circ} \mathrm{C}$, respectively. Bottom: EDX elemental maps revealing the distribution of $\mathrm{Ag}$, $\mathrm{Sb}$ and $\mathrm{S}$ elements at the microscale for $\mathrm{AgSbS}_{2}$ produced at $500{ }^{\circ} \mathrm{C}(\mathrm{Ag} \mathrm{Ka}, \mathrm{Sb} \mathrm{Ka}$ and $\mathrm{S} \mathrm{Ka})$. The unlabelled scale bars represent $10 \mu \mathrm{m}$.

measured carrier mobility and carrier concentration are $81 \mathrm{~cm}^{2} \mathrm{~V}^{-1} \mathrm{~s}^{-1}$ and $1.9 \times 10^{15} \mathrm{~cm}^{-3}$, respectively. These values are comparable to values obtained for $\mathrm{Cu}_{2} \mathrm{FeSnS}_{4}$ (CFTS) films ${ }^{63}$. Hall effect measurements revealed that the films exhibit p-type conductivity.

Secondary electron scanning electron microscopy (SEM) was used to interrogate the surface morphologies of the powders produced at different temperatures. Cubic structures are revealed for powders produced at $400{ }^{\circ} \mathrm{C}$ which changed to a porous appearance when the temperature of the synthesis was increased to $450{ }^{\circ} \mathrm{C}$. When the temperature was increased to $500^{\circ} \mathrm{C}$, the morphology changed to flakes as shows in Fig. 6 and ESI (Fig. S2.6). Influence of the increasing temperature on the crystal structure has been reported by Habe et al. ${ }^{69}$. The $\mathrm{AgSbS}_{2}$ powders prepared at 400,450 and $500{ }^{\circ} \mathrm{C}$ were analysed using energy-dispersive X-ray (EDX). EDX mapping gives information on the spatial distribution of elements at the micro to nanoscale and to ensure that the distribution of elements is homogeneous. Representative elemental mapping (Fig. 6) of these components showed a uniform distribution of the silver, antimony and sulfur. EDX spectra show that the samples consist only of the elements silver, antimony and sulfur, suggesting that decomposition is clean and produces high quality crystalline materials which is consistent with the XRD and Raman data from the same materials (see supporting information for EDX sum spectra Figs. S2.7 to S2.11).

\section{Conclusions}

A novel, efficient and low temperature method for the synthesis of $\mathrm{AgSbS}_{2}$ powders has been demonstrated. Silver(I) ethylxanthate $\left[\mathrm{AgS}_{2} \mathrm{COEt}\right](\mathbf{1})$ and antimony(III) ethylxanthate $\left[\mathrm{Sb}\left(\mathrm{S}_{2} \mathrm{COEt}\right)_{3}\right](2)$ precursors have been used to produce crystalline powders of $\mathrm{AgSbS}_{2}$ with a high degree of atom efficiency. Ternary cubic AgSbS (cubo- $^{-}$ argyrite) was successfully produced which was evidenced by XRD and Raman spectroscopy. XRD data shows that crystallite size increase with increasing synthesis temperature. SEM images show a change in the surface morphology of these powders from cubic crystallites to flakes upon increasing the synthesis temperature. EDX mapping gives a clear indication of the presence of spatially co-localised $\mathrm{Ag}$, Sb and $\mathrm{S}$ with no other elemental impurities. Use of solvents can be avoided altogether through the melt method which has great potential for the mass production of nanocrystalline powders of ternary materials.

\section{Methods}

Methanol (99.8\%), silver nitrate (99.9\%), antimony (III) chloride (99\%), potassium ethyl xanthate (96\%) and chloroform-d (99\%). All chemicals were purchased from Sigma-Aldrich and used as received.

Synthesis of $\left[\mathrm{AgS}_{2} \mathrm{COEt}\right]$ (1). Silver nitrate $(1.7 \mathrm{~g}, 10.0 \mathrm{mmol})$ was dissolved in $20.0 \mathrm{ml}$ of deionised water. The solution was added dropwise to aqueous potassium ethyl xanthate $(2.0 \mathrm{~g}, 10.6 \mathrm{mmol})$ with a constant stirring for $40 \mathrm{~min}$ at room temperature. The silver ethyl xanthate precursor rapidly forms. A shiny green solid of the title compound was obtained by filtration and dried at room temperature. Yield $1.9 \mathrm{~g}(86 \%)$. Melting point (M.p). $150-154{ }^{\circ} \mathrm{C}$ Anal. calc. for $\mathrm{AgS}_{2} \mathrm{COC}_{3} \mathrm{H}_{5}$ (\%): C 15.73, H 2.20, S 27.94, Ag 47.14. Found: C 15.84, H 2.13, S 27.89, Ag 46.91. FT-IR solid $\left(v_{\max } / \mathrm{cm}^{-1}\right)$ : $2978.03(\mathrm{w}), 2938.5(\mathrm{w}), 1472.38(\mathrm{w}), 1355.23(\mathrm{~m}), 1184.08(\mathrm{~s}), 1136.83$ (s), 1012.45 (s), 995.57 (s). ${ }^{13} \mathrm{C}$ NMR: $\sigma 227.55 \mathrm{ppm}\left(\mathrm{S}_{2} \mathrm{C}\right), \sigma 69.49 \mathrm{ppm}\left(\mathrm{CH}_{2}\right)$ and $\sigma 13.92 \mathrm{ppm}\left(\mathrm{CH}_{3}\right)$. 
Synthesis of $\left[\mathrm{Sb}\left(\mathrm{S}_{2} \mathrm{COEt}\right)_{3}\right](2)$. Precursor (2) was prepared as per complex (1), but with antimony trichloride $(2.0 \mathrm{~g}, 8.7 \mathrm{mmol})$ dissolved in $20 \mathrm{ml}$ of methanol. The resulting solution was added dropwise to potassium ethyl xanthate $(4.2 \mathrm{~g}, 26.2 \mathrm{mmol})$ which was dissolved in $80 \mathrm{ml}$ of methanol. The crude product was isolated by filtration and recrystallized from chloroform to give pale yellow crystals. Yield: $3.5 \mathrm{~g}$ (80\%). M.p. $88-92{ }^{\circ} \mathrm{C}$. Anal. Calc. for $\mathrm{Sb}\left(\mathrm{S}_{2} \mathrm{COEt}\right)_{3}(\%)$ : C 22.28, H 3.12, S 39.58, Sb 25.12. Found: C 22.11, H 2.87, S 39.54, Sb 24.46. FT-IR solid $\left(v_{\max } / \mathrm{cm}^{-1}\right): 2988.64(\mathrm{w}), 2938.50(\mathrm{w}), 1468.05(\mathrm{w}), 1359.05(\mathrm{w}), 1186.49(\mathrm{w}), 1109.83(\mathrm{~s})$, 993.64 (s). ${ }^{13} \mathrm{C}$ NMR: $\sigma 222.49 \mathrm{ppm}\left(\mathrm{S}_{2} \mathrm{C}\right), \sigma 72.07 \mathrm{ppm}\left(\mathrm{CH}_{2}\right)$ and $\sigma 13.90 \mathrm{ppm}\left(\mathrm{CH}_{3}\right)$.

Synthesis of $\mathrm{AgSbS}_{2}$ powders. A homogenised mixture of $\left[\mathrm{AgS}_{2} \mathrm{COEt}\right](\mathbf{1})$ and $\left[\mathrm{Sb}\left(\mathrm{S}_{2} \mathrm{COEt}\right)_{3}\right](\mathbf{2}) \mathrm{com}$ plexes (1:1 mol ratio) was placed in a ceramic boat that was subsequently placed in the centre of a glass tube which was then inserted into a Carbolite tube furnace. One end of the glass tube was directly connected to nitrogen gas through a Schlenk line in the fume hood, and the other end of the tube was carefully sealed with a rubber septum. A vacuum was used to remove any oxygen from the glass tube, and the glass tube was then refilled with nitrogen gas. After that the mixture was heated in the Carbolite furnace at $400{ }^{\circ} \mathrm{C}, 450{ }^{\circ} \mathrm{C}$ and $500{ }^{\circ} \mathrm{C}$, respectively and kept it at each temperature for $1 \mathrm{~h}$ under nitrogen atmosphere to produce $\mathrm{AgSbS}_{2}$ powders. The final product was collected for further analysis after the system was slowly cooled to room temperature. In addition, $\mathrm{AgSbS}_{2}$ thin films were also deposited by spin coating technique using the same complexes, as per the synthesis of $\mathrm{AgSbS}_{2}$ powders. Full details of thin film deposition and characterisation are presented in Sect. 3 of ESI.

Materials characterisation. A Specac single reflectance ATR instrument $\left(4000-400 \mathrm{~cm}^{-1}\right)$ with resolution $4 \mathrm{~cm}^{-1}$ was used to record the infrared spectra (IR). Melting points of the complexes were obtained using a Barloworld SMP10. ${ }^{13} \mathrm{C}$ NMR spectra were obtained using a Bruker AC400 FT-NMR spectrometer. Elemental analysis was performed with a Carlo Erba EA 1108 instrument. Thermogravimetric analysis (TGA), was performed using a Seiko SSC/S200 at a heating rate of $10^{\circ} \mathrm{C} \mathrm{min}^{-1}$ under nitrogen. Powder X-ray diffraction (XRD) measurements were carried out by a Bruker Xpert diffractometer, utilising $\mathrm{Cu}$-Ka radiation (1.5406 ̊̊). Raman spectra were recorded using a Renishaw 1000 microscope system equipped with laser excitation of $514 \mathrm{~nm}$. Scanning electron microscopy (SEM) images were obtained using a Tescan SC Oxford SEM. Electrical properties of the thin films were measured using the Van Der Pauw method by means of a custom-build Hall effect measurement system.

Received: 23 September 2020; Accepted: 18 January 2021

Published online: 04 February 2021

\section{References}

1. Matthews, P. D., McNaughter, P. D., Lewis, D. J. \& O'Brien, P. Shining a light on transition metal chalcogenides for sustainable photovoltaics. Chem. Sci. 8, 4177-4187. https://doi.org/10.1039/C7SC00642J (2017).

2. Xuelian, Y. et al. $\mathrm{Cu}_{2} \mathrm{ZnSnS}_{4}-\mathrm{Pt}$ and $\mathrm{Cu}_{2} \mathrm{ZnSnS}_{4}-\mathrm{Au}$ heterostructured nanoparticles for photocatalytic water splitting and pollutant degradation. J. Am. Chem. Soc. 26, 9236-9239. https://doi.org/10.1021/ja502076b (2014).

3. Green, M. A., Emery, K., King, D. L., Igari, S. \& Warta, W. Solar cell efficiency tables (Version 55). Prog. Photovolt. 28, 3-15. https ://doi.org/10.1002/pip.3228 (2020).

4. Gusain, M., Rawat, P. \& Nagarajan, R. Soft chemical synthesis of $\mathrm{Ag}_{3} \mathrm{SbS}_{3}$ with efficient and recyclable visible light photocatalytic properties. Mater. Res. Bull. 60, 872-875. https://doi.org/10.1016/j.materresbull.2014.09.084 (2014).

5. Tubtimtae, A., Huang, C.-L., Shi, J.-B. \& Lee, M.-W. $\mathrm{Ag}_{3} \mathrm{SbS}_{3}$ thin films formed by annealing hydrothermally synthesized $\mathrm{Ag}_{3} \mathrm{SbS}_{3}$ nanoparticles. Mater. Lett. 177, 58-60. https://doi.org/10.1016/j.matlet.2016.04.165 (2016).

6. Schönau, K. A. \& Redfern, S. A. T. High-temperature phase transitions, dielectric relaxation, and ionic mobility of proustite, $\mathrm{Ag}_{3} \mathrm{AsS}_{3}$, and pyrargyrite, $\mathrm{Ag}_{3} \mathrm{SbS}_{3}$. J. Appl. Phys. 92, 7415-7424. https://doi.org/10.1063/1.1520720 (2002).

7. Kunioka, A. \& Sakai, Y. Electrical and optical properties of CdO-Si junctions. Jpn. J. Appl. Phys. 7, 1138. https://doi.org/10.1143/ JJAP.7.1138 (1968).

8. Sreedhar, A. K., Sharma, B. L. \& Purohit, R. K. Efficiency calculations of heterojunction solar energy converters. IEEE Trans. Electron Devices. 16, 309-312. https://doi.org/10.1109/T-ED.1969.16746 (1969).

9. Goodwin, A. \& Selway, P. Gain and loss processes in GaAlAs-GaAsheterostructure lasers. IEEE J. Quantum Electron. 6, 285-290. https://doi.org/10.1109/JQE.1970.1076463 (1970).

10. Castellano, A. GaSe detectors for X-ray beams. Appl. Phys. Lett. 48, 298-299. https://doi.org/10.1063/1.96586 (1986).

11. Vopdorp, C. \& Vrakking, J. Photo-effects in isotypeheterojunctions. Solid-State Electron. 10, 955-971. https://doi.org/10.1016/00381101(67)90011-1 (1967).

12. Mali, S. S., Patil, P. S. \& Hong, C. K. Low-cost electrospun highly crystalline kesterite $\mathrm{Cu}_{2} \mathrm{ZnSnS}_{4}$ nanofiber counter electrodes for efficient dye-sensitized solar cells. ACS Appl. Mater. Interfaces. 3, 1688-1696. https://doi.org/10.1021/am404586n (2014).

13. Yang, B. et al. $\mathrm{CuSbS}_{2}$ as a promising earth-abundant photovoltaic absorber material: a combined theoretical and experimental study. Chem. Mater. 26, 3135-3143. https://doi.org/10.1021/cm500516v (2014).

14. Revaprasadu, N. Nanoscience Vol. 6 (Roy. Soc. Chem, United Kingdom, 2020).

15. Gervas, C. et al. Effect of cationic disorder on the energy generation and energy storage applications of $\mathrm{NixCo}_{3-} \mathrm{xS}_{4}$ thiospinel. $R S C$ Adv. 8, 24049-24058. https://doi.org/10.1039/C8RA03522A (2018).

16. He, Q. et al. The role of Mott-Schottkyheterojunctions in $\mathrm{Ag}-\mathrm{Ag}_{8} \mathrm{SnS}_{6}$ as Counter electrodes in dye-sensitized solar cells. Chemsuschem 8, 817-820. https://doi.org/10.1002/cssc.201403343 (2015).

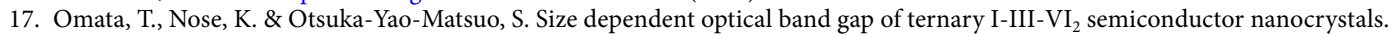
J. Appl. Phys. 105, 073106. https://doi.org/10.1063/1.3103768 (2009).

18. Rabhi, A., Kanzari, M. \& Rezig, B. Optical and structural properties of $\mathrm{CuSbS}_{2}$ thin films grown by thermal evaporation method. Thin Solid Films 517, 2477-2480. https://doi.org/10.1016/j.tsf.2008.11.021 (2009).

19. Avellaneda, D., Delgado, G., Nair, M. T. S. \& Nair, P. K. Structural and chemical transformations in SnS thin films used in chemically deposited photovoltaic cells. Thin Solid Films 515, 5771-5776. https://doi.org/10.1016/j.tsf.2006.12.078 (2007). 
20. Bouaziz, M., Amlouk, M. \& Belgacem, S. Structural and optical properties of $\mathrm{Cu}_{2} \mathrm{SnS}_{3}$ sprayed thin films. Thin Solid Films 517, 2527-2530. https://doi.org/10.1016/j.tsf.2008.11.039 (2009).

21. González, J. O. et al. AgSb( $\left.\mathrm{S}_{\mathrm{x}} \mathrm{Se}_{1-\mathrm{x}}\right)_{2}$ thin films for solar cell applications. Mater. Res. Bull. 48, 1939-1945. https://doi.org/10.1016/j. materresbull.2013.01.040 (2013).

22. Capistrán-Martínez, J. \& Nair, P. K. Photoconductive thin films of $\mathrm{AgSbS}_{2}$ with cubic crystalline structure in solar cells. Phys. Status Solidi A 212, 2869-2876. https://doi.org/10.1002/pssa.201532496 (2015).

23. Galdámez, A., López-Vergara, F., Veloso Cid, N., Manríquez, V. \& Ávila, R. E. Copper substitutions in synthetic miargyritea-AgSbS mineral: synthesis, characterization and dielectrical properties. Mater. Chem. Phys. 143, 1372-1377. https://doi.org/10.1016/j. matchemphys.2013.11.048 (2014).

24. Bera, T. K. et al. Soluble direct-band-gap semiconductors $\mathrm{LiAsS}_{2}$ and $\mathrm{NaAsS}_{2}$ : large electronic structure effects from weak As $\cdots \mathrm{S}$ interactions and strong nonlinear optical response. Angew. Chem. Int. Ed. Engl. 47, 7828-7832. https://doi.org/10.1002/anie.20080 1392 (2008).

25. Bera, T. K. et al. Soluble semiconductors $\mathrm{AAsSe}_{2}(\mathrm{~A}=\mathrm{Li}, \mathrm{Na})$ with a direct-band-gap and strong second harmonic generation: a combined experimental and theoretical study. J. Am. Chem. Soc. 132, 3484-3495. https://doi.org/10.1021/ja9094846 (2010).

26. Hamam, M., El-Gendy, Y. A., Selim, M. S., Teleb, N. H. \& Salem, A. M. Temperature dependence of the structural and optical properties of the amorphous-to-crystalline transition in $\mathrm{AgSbSe}_{2}$ thin films. ChalcogenideLett. 6, 359-365 (2009).

27. Garza, J. G., Shaji, S., Rodriguez, A. C., Das Roy, T. K. \& Krishnan, B. AgSbSe2 and AgSb(S, Se)2 thin films for photovoltaic applications. Appl. Surf. Sci. 257, 10834-10838. https://doi.org/10.1016/j.apsusc.2011.07.115 (2011).

28. Soliman, H. S., Abdel-Hady, D. \& Ibrahim, E. Optical properties of thermally vacuum evaporated AgSbSe ${ }_{2}$ thin films. J. Phys. Condens. Matter. 10, 847-856. https://doi.org/10.1088/0953-8984/10/4/013 (1998).

29. Bindu, K., Campos, J., Nair, M. T. S., Sánchez, A. \& Nair, P. K. Semiconducting AgSbSe $e_{2}$ thin film and its application in a photovoltaic structure. Semicond. Sci. Technol. 20, 496-504. https://doi.org/10.1088/0268-1242/20/6/004 (2005).

30. Wang, K., Steimer, C. \& Wuttig, M. Phase change properties of ternary AgSbSe 2 chalcogenide films. J. Ovonic Res. 2, 61-65 (2006).

31. Baranova, E. R. et al. Electric conductivity and dielectric permittivity of mixed electronic-ionic conductivity compounds $(\mathrm{BS})_{1-\mathrm{x}}(\mathrm{DAsS})_{\mathrm{x}}(\mathrm{B}=\mathrm{Ge}, \mathrm{Pb} ; \mathrm{D}=\mathrm{Ag}, \mathrm{Cu})$. Solid State Ion. 124, 255-261. https://doi.org/10.1016/S0167-2738(99)00209-X (1999).

32. Baranova, E. R. et al. Ionic conductivity in $(\mathrm{AS})_{1-\mathrm{x}}\left(\mathrm{AgSbS}_{2}\right)_{\mathrm{x}},(\mathrm{A}=\mathrm{Ge}, \mathrm{Sn}, \mathrm{Pb})$. Solid State Ion. 146, 415-421. https://doi.org/10.1016/ S0167-2738(01)01025-6 (2002).

33. Geller, S. \& Wernick, J. H. Ternary semiconducting compounds with sodium chloride-like structure: $\mathrm{AgSbSe}_{2}, \mathrm{AgSbTe}_{2}, \mathrm{AgBiS}_{2}$, $\mathrm{AgBiSe}_{2}$. ActaCrystallogr. 12, 46-54. https://doi.org/10.1107/S0365110X59000135 (1959).

34. Smith, J. V., Pluth, J. J. \& Han, S.-X. Crystal structure refinement of miargyrite, AgSbS 2 . Mineral. Mag. 61, 671-675. https://doi. org/10.1180/minmag.1997.061.408.05 (1997).

35. Kelleher, I., Redfern, S. A. T. \& Pattrick, R. A. D. Cadmium substitution in miargyrite $\left(\mathrm{AgSbS}_{2}\right)$ and related phases: an experimental reconnaissance. Mineral. Mag. 60, 393-401. https://doi.org/10.1180/minmag.1996.060.400.01 (1996).

36. Hofmann, W. Die struktur von miargyrit, AgSbS 2 . B PreussAkadWiss. 24, 111-119 (1938).

37. Knowles, C. R. A redetermination of the structure of miargyrite, AgSbS $_{2}$. ActaCrystallogr. 17, 847-851. https://doi.org/10.1107/ S0365110X64002274 (1964).

38. Effenberger, H., Paar, W. H., Topa, D., Criddle, A. J. \& Fleck, M. The new mineral baumstarkite and a structural reinvestigation of aramayoite and miargyrite. Am. Mineral. 87, 753-764. https://doi.org/10.2138/am-2002-5-619 (2002).

39. Maćkowski, S., Janik, E., Kyrychenko, F. \& Kossut, J. Magneto-optical properties of CdTe quantum wells with ternary MgMnTe and quaternary CdMnMgTe barriers. Thin Solid Films 367, 223-226. https://doi.org/10.1016/S0040-6090(00)00694-5 (2000).

40. Wagner, T. et al. Amorphous chalcogenide AgSbS films prepared by pulsed laser deposition. Appl. Phys. A. 79, 1561-1562. https ://doi.org/10.1007/s00339-004-2847-z (2004).

41. Gutwirth, J. et al. On RF magnetron-sputtering preparation of Ag-Sb-S thin films. J. Phys. Chem. Solids 68, 835-840. https://doi. org/10.1016/j.jpcs.2007.03.030 (2007).

42. Houška, J. et al. Laser ablation of $\mathrm{AgSbS}_{2}$ and cluster analysis by time-of-flight mass spectrometry. Rapid Commun. Mass Spectrom. 23, 1715-1718. https://doi.org/10.1002/rcm.4048 (2009).

43. Nair, P. S., Radhakrishnan, T., Revaprasadu, N., Kolawole, G. \& O’Brien, P. Cadmium ethylxanthate: a novel single-source precursor for the preparation of CdS nanoparticles. J. Mater. Chem. 9, 2722-2725. https://doi.org/10.1039/B202072F (2002).

44. Rath, T., MacLachlan, A. J., Brown, M. D. \& Haque, S. A. Structural, optical and charge generation properties of chalcostibite and tetrahedrite copper antimony sulfide thin films prepared from metal xanthates. J. Mater. Chem. A 47, 24155-24162. https://doi. org/10.1039/C5TA05777A (2015).

45. Masikane, S. C. et al. Important phase control of indium sulfide nanomaterials by choice of indium (III) xanthate precursor and thermolysis temperature. Eur. J. Inorg. Chem. 10, 1421-1432. https://doi.org/10.1002/ejic.201900007 (2019).

46. Alderhami, S. A. et al. Accessing $\gamma-\mathrm{Ga}_{2} \mathrm{~S}_{3}$ by solventlessthermolysis of gallium xanthates: a low-temperature limit for crystalline products. Dalton Trans. 48, 15605-15612. https://doi.org/10.1039/C9DT02061F (2019).

47. Akhtar, M., Malik, M. A., Tuna, F. \& O'Brien, P. synthesis of iron sulfide nanocrystals from tris (O-alkylxanthato) iron (III) complexes. J. Mater. Chem. A. 31, 8766-8774. https://doi.org/10.1039/C3TA12178J (2013).

48. Saah, S. A. et al. $\mathrm{PbS}_{\mathrm{x}} \mathrm{Se}_{1-\mathrm{x}}$ thin films from the thermal decomposition of lead(II) dodecylxanthate and bis(N, N-diethyl-N'naphthoylselenoureato)lead(II) precursors. J. Mater. Sci. 53, 4283-4293. https://doi.org/10.1007/s10853-017-1836-5 (2018).

49. Masikane, S. C. et al. Important phase control of indium sulfide nanomaterials by choice of indium(III) xanthate precursor and thermolysis temperature. Eur. J. Inorg. Chem. 10, 1421-1432. https://doi.org/10.1002/ejic.201900007 (2019).

50. Saah, S. A., Khan, M. D., Awudza, J. A., Revaprasadu, N. \& O’Brien, P. A facile green synthesis of ultranarrowPbSnanorods. J. Inorg. Organomet. Polym. 29, 2274-2281. https://doi.org/10.1007/s10904-019-01185-1 (2019).

51. Al-Shakban, M. et al. Novel xanthate complexes for the size-controlled synthesis of copper sulfide nanorods. Inorg. Chem. 56, 9247-9254. https://doi.org/10.1021/acs.inorgchem.7b01288 (2017).

52. Zhang, C. et al. Size-controlled synthesis of monodisperse $\mathrm{Ag}_{2} \mathrm{~S}$ nanoparticles by a solventlessthermolytic method. Mater. Lett. 85, 77-80. https://doi.org/10.1016/j.matlet.2012.06.112 (2012).

53. Khan, M. D., Murtaza, G., Revaprasadu, N. \& O’Brien, P. Synthesis of chalcopyrite-type and thiospinel minerals/materials by low temperature melts of xanthates. Dalton Trans. 47, 8870-8873. https://doi.org/10.1039/C8DT00953H (2018).

54. Alqahtani, T. et al. Synthesis of $\mathrm{Bi}_{2-2 \mathrm{x}} \mathrm{Sb}_{2 \mathrm{x}} \mathrm{S}_{3}(0 \leq \mathrm{x} \leq 1)$ solid solutions from solventlessthermolysis of metal xanthate precursors. J. Mater. Chem. C 6, 12652-12659. https://doi.org/10.1039/C8TC02374C (2018).

55. Fradler, C. et al. Flexible polymer/copper indium sulfide hybrid solar cells and modules based on the metal xanthate route and low temperature annealing. Sol. Energy Mater. Sol. Cells. 124, 117-125. https://doi.org/10.1016/j.solmat.2014.01.043 (2014).

56. Leventis, H. C. et al. Nanostructured hybrid polymer-inorganic solar cell active layers formed by controllable in situ growth of semiconducting sulfide networks. NanoLett. 10, 1253-1258. https://doi.org/10.1021/nl903787j (2010).

57. Rath, T. et al. Direct extreme UV-lithographic conversion of metal xanthates into nanostructured metal sulfide layers for hybrid photovoltaics. J. Mater. Chem. A. 1, 11135-11140. https://doi.org/10.1039/C3TA12592K (2013).

58. Lewis, E. A. et al. In situ synthesis of PbSnanocrystals in polymer thin films from lead(II) xanthate and dithiocarbamate complexes: evidence for size and morphology control. Chem. Mater. 27, 2127-2136. https://doi.org/10.1021/cm504765z (2015).

59. Al-Shakban, M., Xie, Z., Savjani, N., Malik, M. A. \& O'Brien, P. A facile method for the production of SnS thin films from melt reactions. J. Mater. Sci. 51, 6166-6172. https://doi.org/10.1007/s10853-016-9906-7 (2016). 
60. Al-Shakban, M. et al. The synthesis and characterization of $\mathrm{Cu}_{2} \mathrm{ZnSnS}_{4}$ thin films from melt reactions using xanthate precursors. J. Mater. Sci. 52, 12761-12771. https://doi.org/10.1007/s10853-017-1367-0 (2017).

61. McNaughter, P. D. et al. The effect of alkyl chain length on the structure of lead(II) xanthates and their decomposition to PbS in melt reactions. Dalton Trans. 45, 16345-16353. https://doi.org/10.1039/C6DT02859D (2016).

62. Buckingham, M. A., Catherall, A. L., Hill, M. S., Johnson, A. L. \& Parish, J. D. Aerosol-assisted chemical vapor deposition of CdS from xanthate single source precursors. Cryst. Growth Des. 17, 907-912. https://doi.org/10.1021/acs.cgd.6b01795 (2017).

63. Alanazi, A. M. et al. A molecular precursor route to quaternary chalcogenide CFTS $\left(\mathrm{Cu}_{2} \mathrm{FeSnS}_{4}\right)$ powders as potential solar absorber materials. RSC Adv. 9, 24146-24153. https://doi.org/10.1039/C9RA02926E (2019).

64. Kibasomba, P. M. et al. Strain and grain size of $\mathrm{TiO}_{2}$ nanoparticles from TEM, Raman spectroscopy and XRD: the revisiting of the Williamson-Hall plot method. Results Phys. 9, 628-635. https://doi.org/10.1016/j.rinp.2018.03.008 (2018).

65. Zhou, B. et al. Monodisperse $\mathrm{AgSbS}_{2}$ nanocrystals: size-control strategy, large-scale synthesis, and photoelectrochemistry. Chem. Eur. J. 21, 11143-11151. https://doi.org/10.1002/chem.201501000 (2015).

66. Almanqur, L. et al. Synthesis of iron sulfide thin films and powders from new xanthate precursors. J. Cryst. Growth. 522, 175-182. https://doi.org/10.1016/j.jcrysgro.2019.05.029 (2019).

67. Wang, T., Farvid, S. S., Abulikemu, M. \& Radovanovic, P. V. Size-tunable phosphorescence in colloidal metastable $\gamma-\mathrm{Ga}_{2} \mathrm{O}_{3}$ nanocrystals. J. Am. Chem. Soc. 132, 9250-9252. https://doi.org/10.1021/ja101333h (2010).

68. Minceva-Sukarova, B. et al. Vibrational spectra of $\mathrm{M}^{\mathrm{I}} \mathrm{M}^{\mathrm{III}} \mathrm{S}_{2}$ type synthetic minerals $\left(\mathrm{M}^{\mathrm{I}}=\mathrm{Tl}\right.$ or $\mathrm{Ag}$ and $\mathrm{M}^{\mathrm{III}}=\mathrm{As}$ or Sb). J. Mol. Struct. 651-653, 181-189. https://doi.org/10.1016/S0022-2860(03)00105-4 (2003).

69. Versavel, M. Y. \& Haber, J. A. Structural and optical properties of amorphous and crystalline antimony sulfide thin-films. Thin Solid Films 515, 7171-7176. https://doi.org/10.1016/j.tsf.2007.03.043 (2007).

70. Lewis, D.J \& Winpenny, R.E.P. Paul O’Brien. 22 January 1954-16 October 2018 Biog. Mem. Fell. R. Soc. 69, 443-446. https://doi. org/10.1098/rsbm.2019.0041 (2020)

\title{
Acknowledgements
}

Y.T.A. would like to acknowledge the Ministry of education (King Salman scholarship program) for financial support. F.A. and D.J.L. would like to acknowledge funding from EPSRC UK Grant Number EP/R020590/1. The authors thank Prof. David Collison for his guidance and support and the inspiration of Paul O'Brien ${ }^{70}(22$ January 1954-16 October 2018).

\section{Author contributions}

D.J.L. conceived and supervised the project. Y.T.A. performed the experimental work on synthesis and characterization of the precursors and silver antimony sulfide powders and thin films. D.J.L., Y.T.A. and F.A. analysed data. The electrical properties were measured by A.S and M.M. D.J.L., F.A. and Y.T.A. wrote the manuscript.

\section{Competing interests}

The authors declare no competing interests.

\section{Additional information}

Supplementary Information The online version contains supplementary material available at https://doi. org/10.1038/s41598-021-82446-3.

Correspondence and requests for materials should be addressed to D.J.L.

Reprints and permissions information is available at www.nature.com/reprints.

Publisher's note Springer Nature remains neutral with regard to jurisdictional claims in published maps and institutional affiliations.

\begin{abstract}
(c) (1) Open Access This article is licensed under a Creative Commons Attribution 4.0 International License, which permits use, sharing, adaptation, distribution and reproduction in any medium or format, as long as you give appropriate credit to the original author(s) and the source, provide a link to the Creative Commons licence, and indicate if changes were made. The images or other third party material in this article are included in the article's Creative Commons licence, unless indicated otherwise in a credit line to the material. If material is not included in the article's Creative Commons licence and your intended use is not permitted by statutory regulation or exceeds the permitted use, you will need to obtain permission directly from the copyright holder. To view a copy of this licence, visit http://creativecommons.org/licenses/by/4.0/.
\end{abstract}

(C) The Author(s) 2021 